\title{
An Annotated Bibliography of Translation Studies Books Published in 2018 : Part II
}

RANDHEER KOUR

PolizzotTi, MARK. 2018. Sympathy for the Traitor: A Translation Manifesto. Massachusetts: The MIT Press.

The book Sympathy for the Traitor concerns the basic issues encountered in the act of translation; however, it mainly concentrates on literary translation. This book presents a collection of nine papers that appear in it as chapters. The author has attempted to engage with the basic philosophical questions regarding translation like whether the translation is really possible. If possible, whether it really matters? What may render a translation (im)pure? The question of faithfulness and so on. The central focus of this book rests on the ultimate goal of translation. It draws references from literary texts, theories of translation and events to shed light on this core concern. The first chapter argues that the constant struggle to keep a balance between the objective fact (that text is to be translated) and subjective interpretation (of that text by the translator) appears to make the whole process really impossible. A chapter on language purity discusses Benjamin's 'kinship of languages,' and translation theorist Andre Lefevere's 'translationese.' It brings our attention to an important aspect of translation, that, translation theories do not help in major ways to produce a better translation. Chapter four highlights the debate on the matter of faithfulness of the translator. It also addresses the question of the translator's responsibility for the work of translation. A chapter 'The Silences Between' discusses the different mistranslations that occur due to cultural gaps and the steps taken to bridge those gaps. The author himself being a translator gives illustrations from different literary texts and her translations, to shed light on the question of judging a translation in chapter 'Sympathy 
for the Traitor'. The chapter titled 'Verse and Controverse' deals with the arguments about the translation of poetry and the discussion moves around the translations of Pound and Nabokov. 'On the Fringe' starts with the question, can everything be translated? This chapter takes up the issues of 'lipogrammatic novels,' 'difficult authors,' 'untranslatables,' sound-based translations and so on. The last chapter takes on an inevitable question; does translation really matter? The author discusses various misunderstood and misapprehended instances from world politics, references from ancient Holy Scriptures, and modern texts. He validates the role of translation by stating that translation must give enough spaces to those unheard unique voices which have something to say.

MALMKJER KIRSTEN (ed). 2018. The Routledge Handbook of Translation Studies and Linguistics. London: Routledge.

As the title suggests, this handbook offers studies on the multifarious relationship between Translation Studies and Linguistics. It is organized into six sections that further expand into twenty-seven chapters. The handbook comprising research work by thirty-seven scholars from across the globe reflects the diverse possibilities of the interface between the two disciplines. The first part titled 'The nature of language, translation, and interpretation' has four chapters. The first chapter outlines the history of mutual relationships that have developed between the theories of linguistics and the discipline of Translation Studies and interpreting in the 20th and 21st centuries. 'Semiotics and Interpretation' examines the communication of meaning through linguistic signs and signs belonging to other systems, whereas a chapter on 'phonetics, phonology, and interpreting,' explains the role of speech sounds (like pause, speech rate, intonation, stress, etc.) in interpretation. The second part titled 'Meaning Making' also consists of four chapters. It discusses the effect of context on 
non-verbal communication when it is remote and distant. It draws our attention to the rhetoric and oratory, according to the author, which are frequently overlooked in current research in translation and interpretation practices. Part three titled 'Text in Speech and Writing' contains seven chapters. The chapter on text linguistics examines how translation preserves, alters or destroys 'interaction structures' (texts are interaction structures). Mona Baker's paper on stylistic explores the interaction of style and translation in literature, particularly in poetry. A chapter 'Wordplay and Translation' examines the challenge that 'pun' poses in translation where the cultural references differ in two languages concerned. Part four under the title 'Individuals and their Interactions' is divided into four chapters. The chapter on language disorder concludes with a brief discussion on aphasic bilingual patients and their ability to translate. Moritz Schaeffer's paper on language processing reviews different cognitive models used to describe language processing during translation. In 'Sociolinguistics, Translation, and Interpreting,' the author examines various aspects of the relationship between the three disciplines. It suggests that, in the 21 st century, the knowledge of sociolinguistics is likely to become an intrinsic part of competence for translators and interpreters. Part five of this handbook focuses on media and machines in the context of translation and interpretation. The chapter on translation in the news media examines the important concept of 'transediting' (i.e., editing while translating) in news translation and the challenges it poses to translators. Another chapter explores the various translationrelated activities involved in web localization and their social contexts. Part six titled 'Applications' offers three chapters. The first chapter discusses linguistics, translation and interpreting in the context of foreign-language classrooms. The focus of the second chapter is the intricate relationship shared by translation, interpreting and lexicography. The final chapter 
of this handbook explains the major trends in the interaction between language for specific purpose LSP (domain-specific language) and translation, and the practical issues concerning this field. A noticeable aspect of this handbook is that every chapter has a list of books suggested for further reading.

Boase-Beier, Jean, Lina Fisher and Hiroko Furukawa (eds). 2018. The Palgrave Handbook of Literary Translation. Switzerland: Macmillan Palgrave.

This collaborative work elucidates different aspects of Literary Translation (LT) as well as the various dimensions of the theory-practice relationship. The editors of this book consider LT as the sub-discipline of TS, discuss various case studies and provide a better understanding of this relationship. Twenty-six scholars have contributed to this voluminous work comprising twenty-five chapters in three sections. The introductory chapter takes up the issue of methodologies in case studies involving LT. The nine chapters in the first section 'Literary Translation and Style' largely discuss the magnitude of style in the translation of the poetry and the novel. $\mathrm{H}$. Cockerill discusses two foreign linguistic elements that appeared in six Japanese translations of Dostoevsky's Crime and Punishment. Jean Boase does a narrow and in-depth analysis of German Holocaust poet Nelly Sachs and concludes that the broader context of her poetry gives insights into how her work might be translated in the future. A. Fawcett in her case study discusses the aspect of 'iconicity' which becomes a specific problem of untranslatability in the poetics of 20thcentury Dutch poets. S. Klinger, in her descriptive-explanatory case study of the three translations (English, German, and Spanish) of a Chilean writer, illustrates how a genre shift occurs in translation and what effect it has on the reading experience. H. Furukawa's paper, adopting a process and product-oriented descriptive approach, explores the convention 
of overly feminised representation of women in Japanese translation. The second part tries to configure the relationship between the author, the translator and the reader in the nine chapters that follow. K. Malmkjaer locates the gap, between the evolution and the use of the two concepts, "Angst" and "Repetition," present in the work of Soren Kierkegaard and two other Danish Novelists, Tom Kristensen and Peter Hoeg, and in the English translation of their work. M. Perteghella traces the journey of theatre translation of Shakespeare's The Tempest from the source text to the collaborative translated script for a theatre performance in the Italian language. F. R. Jones maps the trajectory of the founding father of TS, James S. Holmes, a dedicated poetry translation expert (Dutch to English translation) and his 'network phenomenon'. Susan Bassnett explains the role of Josephine Balmer (a creative translator of ancient Greek and Latin texts for new readers) in blurring the lines between the original text of the ancient world and its translations. The third section explores the affinity identity shares with literary translation. In this section, Kathryn Batchelor paper studies Sunjata (an African epic in English translations) and examines how paratexts become key sites where translator mediates and controls the voice of the source text performer. M. Chozick's case study tries to unfold the different layers of the complexities of purity associated with every translated version of Genji (Japanese text of the eleventh century). On the whole, this book encompasses to a great extent the various aspects of literary translations, its reception in different parts of the world and the new challenges it poses before us to deal with.

ScotT, Clive. 2018. The Work of Literary Translation. London: Cambridge University Press.

The book titled 'The Work of Literary Translation' is divided into three parts and spread through eight chapters. The first 
part 'Thinking One's Way into Literary Translation: Concepts and Reading,' consists of twelve sub-headings that precede chapter one of the second part. Part one engages with the different dimensions of the language of translation in oral and written forms, besides, it includes the cultural context, the issues of untranslatability, multilingualism and so on. The author in this book gives extension to his earlier argument which describes translation as 'phenomenology of reading,' rejecting the conventional one as an interpretation of the text. Part two 'Translation among the Disciplines' has four chapters, discussing translation in relation to ecology, anthropology, comparative literature, and aesthetics. The author Clive Scott examines the ecological functions of translation from three anthropological concerns. He negates the idea of considering translation as a product, rather considers it as a process of making a piece of language, which becomes an unfolding and encompassing ecological event. He also explores how anthropological awareness helps in understanding the translation process. He stresses that translation must be removed from any sense of native space and must be treated as nomadic. In the textual analysis of a translated poem, he argues that the source text is an instrument by which the translator establishes a temporary comparative literary position for his/her writing. The four chapters in part three, which is entitled 'The Paginal Art of Translation', explores the art of translation. In the English translation of poems, Scott tries to explore how the margin, punctuation, and typography affect the rhythm of the poem. By closely examining the variables of the paginal space of a prose poem, the author tries to explain the interplay of margin and rhythm in the translation. He emphasizes that translators must write for pages and not for the text, because, according to him, page expresses the dynamics of the text by activating its vocal modalities. He concludes that his versions of translation are without methodologies and code 
of practice. It is fundamentally trans-disciplinary, mobile and open-ended.

BAtChelor, KATHRYN. 2018. Translation and Paratext. London: Routledge.

According to a French literary theorist Gerard Genette, what enables a text to become a book is 'Paratext'. This book is an attempt to understand the concept of paratext in the context of Translation Studies research. It is a part of a series of translation theories explored. This volume is divided into three parts containing eight chapters. The first part critically analyzes the existing scholarship on 'Paratext'. Three case studies are discussed in the second part. The concluding part outlines a theory of paratextuality for Translation Studies research. The first three chapters are Genette's Paratext, Paratext in digital media, Paratext in communication and Translation Studies. Chapter one discusses the different typologies of Genette's concepts of paratext. The second chapter identifies six key themes of paratext-related translation research. The author explains the functions and characteristics of the paratexts of digital media in the third chapter. The first case study discusses the dubious term 'authorized translation' in the paratext of the English translation of Neitzche's work. The second case study discusses the paratexts of Contemporary Western Translation Studies CWTS series and other related books published in Chinese editions. The author explores how the idea of Mao 'making the foreign serve china' spread across the paratexts of these translation work, and why it was endorsed by Chinese authors and scholars. The third case study assesses the paratexts of video on demand service 'Walter Presents.' It explains how the personal curating nature of Walter Luzzolino becomes its key selling point among British audiences. Based on the discussion in the previous chapters, the final section of this book theorizes the term 
paratextuality for translation in two chapters. In the first chapter, the author proposes a definition of paratext and gives it interpretation as well. He delineates a corpus of paratext for research questions in Translation Studies. The last chapter explores different avenues of paratext research in translation. It studies paratextual conventions. It deals with the question of methodology, translation process-oriented research. Batchelor addresses different research questions to establish the importance and relevance of the study of paratext in the discipline of Translation Studies.

Belle, Marie-Alice And BRenda M. Hoisington (eds.). 2018. Thresholds of Translation; Paratexts, Print, and Cultural Exchange in Early Modern Britain (1473-1660). Switzerland: Palgrave Macmillan.

This book is an outcome of a research project and research activities that took place at the University of Montreal. This volume is divided into two parts, and there are eleven chapters including the introduction. Part one offers five essays that explore the varieties of paratextual practices in early modern English and Scottish translations of a wide range of genres, book formats, classical translations, and modern political treatise. In the second part, there are six case studies. In the chapter 'Matter in the Margins', the author argues that the margins of the book of translation act as a zone of thought and intellectual negotiations where the matter of the text unfolds, where it is explored and identified. Chapter three critically examines the early modern works of translations from Lawrence Venuti concept of 'invisibility of the translator. In this chapter, he makes a point of striking visibility granted in engraved and woodcut images in early printed books. Chapter four focuses on the underexplored area of titles of translated work of the early modern period. This essay discusses the relationship between text and title, the agency involved in 
exercising authority in choosing the title, and the title as a marketing device. Joyce Boro paper on 'Spain in Translation' argues that the translation of one decade (1614-1625) is the result of the Anglo-Spanish political relation in which marriage matches between the two was the key factor. He asserts that the paratextual material influences the target reader in a certain way and discusses how strategically they obscure or announce their Spanishness. The five case studies discussed in part second are the translation of Horace, Virgil, Virgilio, Petrarch and Thomas More. The sixth case study focuses on two English booksellers and the English book trade. Marie Belle's paper explores the horizontal connection between the translated manuscript of the text and its print version. Alessandra's paper explores the different strategies and relations involved in the paratextual space of Scottish translation of Petrarch's Trionfi. Cottegnies's paper examines the paratext of Horace's 'The Art of Poetry' (English translation) by Ben Johnson to unveil Johnson's rhetoric of authorship and the translation. It also explains how Johnson's translation replaces the original, merging the roles of authors and translators. The last chapter of this book looks at the paratexts of the bookseller's catalogue to examine their advertising strategies to list some work as vendible translation in vernacular English book trade between 1640 and 1660. There are eleven contributors to this volume.

TyuleneV, Sergey. 2018. Translation in the Public Sphere. Switzerland: Palgrave Macmillan.

As the title suggests this book draws the attention of the readers to the importance of translation in the public sphere (PS). It employs PS theories to understand translation behaviour in the public sphere. According to the author, this book caters to the needs of two groups; theorists of PS and scholars/ students of Translation Studies. Not all, but most of 
the examples are taken from Russian's PS because of the author's familiarity with the socio-cultural climate of Russia. There are five chapters in this book. Chapter one 'The Missing Link,' discusses the theories of communicative ecology and the author argues that translation is an indispensable element of communicative ecology of the public sphere. He makes a point that much has been written on PS but the translation was never considered as its prominent feature, which is otherwise an important component that links all its agents. He further argues that the theorization of communicative ecology is also conceptualized without taking translation into its account. According to the author, translation is a fourth layer of the communicative ecology, after social, technological and discursive. The translation appears transparent to the PS theorist. He also pinpoints the absence of translation in Nancy Fraser's theorization of PS as 'transnationalisation.' $\mathrm{He}$ stresses the point that translation must be included in the critical theory of PS. Chapter second, 'Meet Translation,' introduces translation as a variety of types of transfers. It discusses the role of three PS-relevant types of translation used in PS to facilitate public communication. These are; kinetic translation (gestures and body language), intralingual translation (retelling and rewording) and interlingual translation. According to the author, translation plays a vital role in negotiating compromises. In the third chapter titled 'Mediating a Compromise', the author examines translation as an instrument of negotiating a compromise. Viewing translation as a means to achieve a compromise, the author distinguishes three types of compromise in PS; substitution, intersection, and conjunction. The second half of this chapter focuses on 'degrees of translation density,' and cites examples from different online sources. Chapter four 'How Translation Works' discusses Habermas' theorization of Communication Action CA and Strategic Action SA. The author states that in 
cross-communal interactions, whether CA or SA, no crossing of the communal boundary is possible without translation. The last chapter discusses the eighteenth-century PS communication in Russia. It analyzes the public debate that goes around the Great Russian musician PetrIl'ich Tchaikovsky and the role translations play in defining his debatable figure in the public sphere.

SCAMMELL, ClaIRE. 2018. Translation Strategies in Global News: What Sarkozy said in the Suburbs. Switzerland: Palgrave Macmillan.

This book concerns a highly prevalent but underrepresented phenomenon that is news translation. It is extremely beneficial for anyone interested in news translation as it discusses various strategies employed by international news agencies in their attempts for translation. This book belongs to the series called Palgrave Studies in Translating and Interpreting. It contains eight chapters including the introduction and the conclusion. French interior minister (who later became the President of France) Nicholas Sarkozy's speech in 2005, when translated into English in the British press, resulted in an enraging controversy. British news agency 'Reuter' is taken for this case study. The two aspects of translation that acquired prominence in the entire discussion are domestication and foreignisation. It investigates the scope of a 'foreignised' approach to translation in the news as an alternative to 'domestication'. It studies the two key sites of news translation; quotation and culturespecific concepts. The second chapter looks at the role of three big news agencies namely; Reuters, Agence France-Presse, and Associated Press, as providers and translators of foreign news. The analysis of top stories on Reuter websites reflects that quotation is the major portion of news reporting. Chapter three explores the nature of news translation. It also engages in debate with Lawrence Venuti's' domestication and 
foreignisation approach to Translation Studies. It examines the norms for domestication strategies in the news. Chapter four unfolds the problems of domestication strategy used in news translation. This chapter discusses the controversial news event in which, the cultural reality of some French words used by Sarkozy in his speech, when translated into English, could not match the cultural reality of the target language, therefore it became highly controversial. It also explores the degree of domestication and foreignisation in the Reuter corpus. The sixth chapter examines the English translation of French culture-specific concepts in a corpus of Reuters report complemented with the analysis of the Reuters Handbook of Journalism. The analysis finds that higher weightage is given to the domesticating strategies. In chapter seven, the author presents a foreignised approach to news translation. This chapter discusses the strategies that increase the reader's contact with the foreign source language and culture and offers counter accuracy checks for journalists translating the news they are reporting.

SCOTT, BERNARD. 2018. Translation, Brains and the Computer: A Neurolinguistic Solution to Ambiguity and Complexity in Machine Translation. Switzerland: Springer.

The book by Bernard Scott is distinct among the books on translation ever published as it explores Artificial Intelligence (AI) mechanism used by translation developers with special focus on Logos Model. This book is divided into two parts. The first part discusses the foundational theoretical insights of the Logos Model. The second part illustrates this model with French and German translations of English examples with the help of various online Machine Translation (MT) systems like Google Translate, Microsoft's Bing Translator, SYSTRANet, PROMT Translator and LISA Lab's neural MT system. It is highly useful for those who know English, French, and 
German because the illustrations used are from English to French and German translations. The author is the founder of Logos Corporation, a company that worked on its Logos Machine Translation system in 1970. This book is beneficial for those who are pursuing research in MT as it deals with the problems of MT, and also for the MT communities. Chapter three discusses five ambiguities in language that a translator encounters while working on MT from psycholinguistic perspectives. These ambiguities include; lexical-syntactic, sentential-syntactic, sentential-semantic, extra- sentential syntactic. Chapter four focuses on the two regions of brains that are involved with language. They are the prefrontal temporal cortex and the hippocampus and it illustrates how hippocampus has been simulated in Logos Model. Chapter six describes the Logos Model. It analyzes five fundamental decisions that determine its design in translating mental model into a Machine Translation model, which are; how to represent linguistic knowledge internally to the computers, how to store that knowledge, how to apply this stored knowledge to input stream, how to generate target sentences from source analysis and how to cope with complexity. It applies this model with illustrations from French and German translation. It uses other models for comparative purposes like Google GNMT, Bing NMT, and SYSTRA Net. While focusing on the limitation, the author states that the errors that need fixation in MT are virtually limitless. This book describes the Logos Model which emerges from the key assumptions about psycholinguistic and neurolinguistic functions. Complexity poses a big question in MT system and the author of this book argues that the technology underlying the logos model offers a demonstrable solution to the complexity involved in MT, and it is a good step in this direction. 